\title{
"Solo Global Business Erudition Di Solobaru" Town Square Sebagai Pemersatu Sekolah Bisnis Dan Rental Office DENGAN KONSEP HYBRID BUILDING
}

\author{
Muhammad Adzan V., M.D.E. Purnomo, Ana Hardiana \\ Program Studi Arsitektur \\ Jurusan Arsitektur Fakultas Teknik \\ Universitas Sebelas Maret Surakarta \\ Email : valdi.1st@gmail.com
}

\begin{abstract}
Increased investment in various sectors of the economy, providing employment opportunities and entrepreneurship opportunities are greater in Solo Baru Region. Increased business activity needs to be supplemented by the provision of trade facilities, offices and education. Trading facilities and offices are highly developed in Solo Baru in 2016, but for educational facilities to support business activities in Solo Baru yet available. Solo Global Business Erudition (SOLO GLOBE) is present as a place of learning and the development of business activities in Solo Baru multi-functional as the School of Business, Rental Office and Town Square. Design issues are: how the shape and appearance of the building mass of the School of Business, Rental Office and Town Square into a single unified building SOLO GLOBE by applying the concept of building a hybrid, so that the shape and building facades can clarify the function and the privacy of each building. The method used is the method of architectural design. The results obtained are the design of a building SOLO GLOBE which retains the character and privacy between each building functions without harming each other.
\end{abstract}

Keywords: Architecture, Business School, Combination, Hybrid Building, Multifunction, Town Square.

\section{PENDAHULUAN}

Keberadaan Kawasan Solo Baru sebagai Satellite Central Bussiness District (SCBD) dengan berbagai kegiatan baru yang mendukung peranan Kota Solo sebagai pusat pengembangan regional Jawa Tengah bagian timur dan selatan. Solo Baru yang berada pada Kecamatan Grogol, Sukoharjo, Jawa Tengah ini tumbuh dengan pesat. Sejak tahun 2012, sudah terbangun dua mall di Solo Baru yaitu Hartono Mall dan The Park Solo Baru. Selain bangunan perdagangan dan pertokoan, terdapat pula perumahan elit, pabrik serta hotel-hotel baru yang sudah berdiri di kawasan ini. Pada akhir tahun 2014 direncanakan pembangunan rumah sakit bertaraf internasional dan perguruan tinggi di Desa Langenharjo, Solo Baru, berdasarkan informasi yang diperoleh dari solopos.com (8 November 2013).

Dengan meningkatnya investasi diberbagai sektor ekonomi mendorong laju pertumbuhan ekonomi menjadi semakin pesat. Kondisi ini memberikan peluang kerja dan kesempatan berusaha yang lebih besar,
Kawasan Solo Baru menjadi tujuan baru yang menarik bagi arus migrasi. Pertumbuhan dan penyebaran penduduk berada pada sekitar $12,45 \%$ per tahun atau sekitar 108.649 jiwa pada Kecamatan Grogol dengan total jumlah penduduk di Sukoharjo mencapai 869.481 jiwa dengan luas $466.666 \mathrm{~m}^{2}$ (sumber : BPS Sukoharjo 2014). Peningkatan jumlah penduduk Solo Baru nantinya perlu diimbangi dengan penyediaan berbagai fasilitas untuk melayani kebutuhan kota. Beberapa fasilitas pelayanan kota yang penting yaitu fasilitas perkantoran, perdagangan dan pendidikan. Fasilitas perdagangan dan perkantoran sudah sangat berkembang di Solo Baru pada tahun 2016, tetapi untuk fasilitas pendidikan khususnya bisnis yang dapat menunjang kegiatan bisnis di Solo Baru belum tersedia.

Solo Global Business Erudition (SOLO GLOBE) hadir sebagai wadah pengembangan dan pembelajaran kegiatan bisnis dan kewirausahaan di Kawasan Solo Baru dengan fungsi ganda yaitu sebagai Sekolah Bisnis, 
Kantor Sewa dan Town Square. SOLO GLOBE dihadirkan sebagai penunjang dari Gerakan Kewirausahaan Nasional 2013 yang digagas oleh Kementerian Koperasi dan UKM untuk membina dan mendanai masyarakat yang berminat berwirausaha dan mengembangkan bisnisnya. Program yang diusung oleh Gerakan Kewirausahaan Nasional diimplementasikan pada tingkat pusat serta daerah melalui pelatihan nasional dan sosialisasi kewirausahaan di seluruh provinsi di Indonesia. Program ini berisi tentang eksposisi kewirausahaan, magang di perusahaan, pembekalan teknis, keterampilan manajerial bagi wirausaha, dan pengembangan inkubator bisnis melalui perguruan tinggi.

Macam perbedaan fungsi dan kegiatan tersebut akan diwadahi ke dalam satu bangunan dengan menerapkan Konsep Hybrid Building sebagai respon dan solusi penggabungan atas macam perbedaan fungsi dan kegiatan yang akan diwadahi. Gubahan dan tata massa bangunan terbentuk dari pertimbangan prinsip-prinsip konsep bangunan hybrid di mana penggabungan macam perbedaan fungsi bangunan dapat saling mengguntungkan tanpa menggangu privasi antar masing fungi pada bangunan.

\section{METODE}

Metode perancangan desain dimulai dari proses pengumpulan data topografi Kawasan Solo Baru yang didapat melalui observasi dan dokumentasi rupa muka tanah. Data peta kependudukan Solo Baru yang didapat melalui data instansional Pemkot serta melalui situs dan artikel terkait. Data tentang kondisi lingkungan Solo Baru yang didapat dengan observasi dan survey lapangan serta wawancara dengan sumber yang terpercaya.

Pemahaman mengenai Sekolah Tinggi Bisnis, Kantor Sewa dan Town Square di dapatkan dari beberapa literatur terkait, pengumpulan data dari situs resmi bangunan terkait serta studi observasi ke Sekolah Tinggi Bisnis, Kantor Sewa dan Town Square. Kajian pustaka yang terkait dengan Konsep Bangunan Hybrid seperti Buku "Phamlet Architecture"(Fenton, 1985) dan Buku "This Is Hybrid" (Per, Mozas, Arpa, 2011).

Data yang terhimpun kemudian digunakan dalam proses perencanaan (building concept) mengidentifikasi masalah yang ada berdasarkan konsep SOLO GLOBE yang diselesaikan dengan penerapan konsep bangunan hybrid pada bangunan.

Metode perancangan kemudian dilanjutkan pada proses analisis perancangan (building criteria) dilakukan dengan mengolah data yang telah terkumpul dan dikelompokkan berdasarkan pemrograman fungsional, performansi, dan arsitektural.

Pemrograman fungsional bertujuan untuk mengidentifikasi penggunaan bangunan SOLO GLOBE, di antaranya pelaku kegiatan, jenis kegiatan, pola kegiatan, sifat kegiatan, sifat organisasi.

Pemrograman performansi menerjemahkan secara sistematik kebutuhan para pengguna SOLO GLOBE berserta fasilitasnya ke dalam persyaratan pemilihan tapak, persyaratan kebutuhan ruang, persyaratan besaran ruang dan program ruang.

Analisis arsitektural merupakan tahap penggabungan dari hasil identifikasi kedua analisa sebelumnya (fungsional dan performansi). Dalam proses ini akan menganalisa pengolahan ruang (area hybrid), masalah pengolahan tapak, gubahan dan tata massa, serta tampilan bangunan yang sesuai dengan penerapan konsep bangunan hybrid.

\section{ANALISIS}

\subsection{Analisis Peruangan}

\subsubsection{Analisis Kebutuhan Ruang}

Tabel 1.Kebutuhan Ruang

\begin{tabular}{|c|c|c|c|}
\hline FUNGSI & PELAKU & $\begin{array}{l}\text { KEGIAT } \\
\text { AN }\end{array}$ & PERUANGAN \\
\hline $\begin{array}{l}\text { Sekolah } \\
\text { Bisnis }\end{array}$ & $\begin{array}{l}\text { - Mahasisw } \\
\text { - Dosen } \\
\text { - Staff } \\
\text { - Tamu } \\
\text { - Petugas } \\
\text { Service }\end{array}$ & $\begin{array}{l}\text { Belajar } \\
\text { Mengajar }\end{array}$ & $\begin{array}{l}\text { Ruang Kelas } \\
\text { Ruang Dosen } \\
\text { Ruang Admin }\end{array}$ \\
\hline $\begin{array}{l}\text { Kantor } \\
\text { Sewa }\end{array}$ & $\begin{array}{l}\text { - Penyewa } \\
\text { - Tamu } \\
\text { - Pengelola }\end{array}$ & $\begin{array}{l}\text { Bekerja } \\
\text { Rapat }\end{array}$ & $\begin{array}{l}\text { Ruang Kantor } \\
\text { Ruang Rapat }\end{array}$ \\
\hline $\begin{array}{l}\text { Town } \\
\text { Square }\end{array}$ & $\begin{array}{l}\text { - Penyewa } \\
\text { retail } \\
\text { - Pengunju } \\
\text { ng } \\
\text { - Pengelola }\end{array}$ & $\begin{array}{l}\text { Belanja } \\
\text { Rekreasi } \\
\text { Makan } \\
\text { Bertemu }\end{array}$ & $\begin{array}{l}\text { Foodcourt } \\
\text { Retail-retail } \\
\text { Bioskop } \\
\text { Toko Buku } \\
\text { Restoran }\end{array}$ \\
\hline
\end{tabular}

Pada Tabel 1 terlihat kebutuhan peruangan yang dibutuhkan dalam pemenuhan wadah 
SOLO GLOBE berdasarkan masing-masing fungsi bangunannya. Peruangan dalam kawasan bangunan SOLO GLOBE ini kemudian dibagi lagi ke dalam empat kelompok zona ruang kegiatan, yaitu meliputi :

- Kelompok Zona Kegiatan Sekolah Bisnis

- Kelompok Zona Kegiatan Kantor Sewa

- Kelompok Zona Kegiatan Town Square

- Kelompok Zona Kegiatan Area Hybrid

\subsubsection{Analisis Pola Hubungan Ruang}

Analisis ini bertujuan untuk mendapatkan pola peletakan ruang bagi objek rancang bangun berdasarkan pertimbangan ketentuan pola hubungan dan organisasi ruang sebagai berikut:

1. Jenis, sifat, dan hubungan dari kegiatan yang diwadahi, dan pelaku kegiatan.

2. Teori hubungan ruang.

\subsection{Analisis Pengolahan Tapak}

\subsubsection{Analisis Lokasi}

Selain menentukan lokasi yang strategis (di pusat Kawasan Solo Baru), memilih tapak dengan kondisi yang mendukung keberadaan SOLO GLOBE ini sangat menentukan prospek bangunan tersebut.

1. Tujuan

Mendapatkan lokasi yang sesuai yaitu pada pusat Kawasan Solo Baru.

2. Dasar pertimbangan

Posisi tapak strategis untuk ekspos tampilan fisik bangunan, luasan tapak dapat menampung seluruh kebutuhan ruang yang direncanakan.

\subsubsection{Analisis Pencapaian}

Pencapaian ke dalam bangunan harus mudah diakses, mudah dilihat dan memiliki sirkulasi yang aman akan menstimulus orang untuk masuk dalam area bangunan.

1. Tujuan

Menentukan main entrane, menentukan service entrance.

2. Dasar Pertimbangan

Kemudahan akses, sirkulasi tapak yang aksesibel, arus kendaraan dan potensi jalan, tingkat keamanan.

3. Proses analisis

Main Entrance (ME)

Mudah dijangkau dan terlihat dengan jelas.

Menghadap langsung ke arah jalan untuk kemudahan sirkulasi kendaraan masuk dan ke luar tapak.

Side Entrance (SE)

Tidak mengganggu keberadaan ME dan membantu sirkulasi servis serta pengunjung.

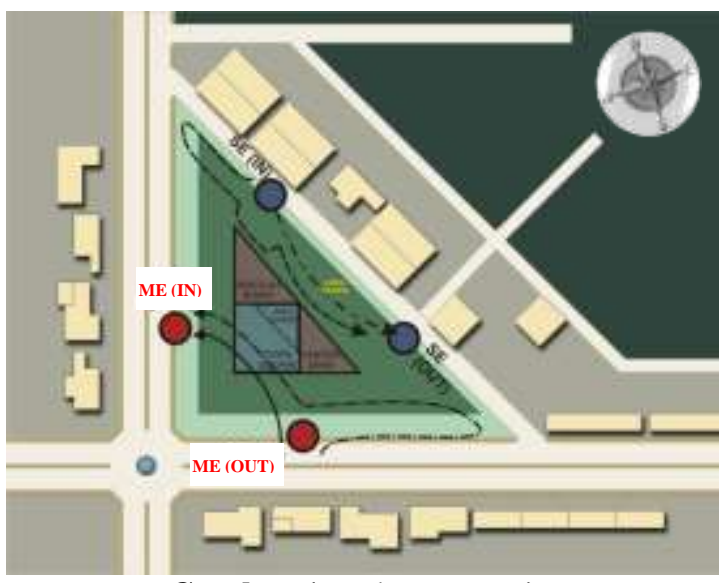

Gambar 1. Pola Pencapaian

Pada Gambar 1 terlihat bahwa ME terletak di sisi barat karena mudah dijangkau dengan berbagai jenis kendaraan serta menghadap langsung ke arah jalan utama. Untuk SE yang difungsikan untuk kepentingan servis, terletak pada sisi timur tapak agar tidak menggangu keberadaan ME tetapi tetap dapat membantu sirkulasi pengunjung.

\subsubsection{Analisis Pemintakatan (Penzoningan)}

Pemintakatan berdasarkan sifat kegiatan dan keadaan dalam tapak dilakukan sebagai acuan dalam penataan peruangan, namun tetap memperhatikan penerapan konsep bangunan hybrid.

a. Tujuan

Menentukan mintakat (zoning) berdasarkan sifat kegiatan dan keadaan pada tapak serta penerapan disperate program pada zoning bangunan.

b. Dasar pertimbangan

Analisis peruangan, analisis pengolahan tapak, analisis konsep bangunan hybrid.

c. Proses analisis

Persyaratan ruang berdasarkan kelompok kegiatan dan analisis pengolahan tapak serta analisis konsep bangunan hybrid.

Tabel 2. Persyaratan Ruang

\begin{tabular}{cccc} 
ZONA & KEL. & PERSYA & KONSEP \\
& RUANG & RATAN & HYBRID \\
\hline
\end{tabular}




\begin{tabular}{|c|c|c|c|}
\hline Publik & $\begin{array}{l}\text { - Town } \\
\text { Square } \\
\text { - Area } \\
\text { Hybrid } \\
\text { (Foodhall) }\end{array}$ & $\begin{array}{l}\text { Pencapaian } \\
\text { mudah } \\
\text { View from/to } \\
\text { site menjadi } \\
\text { pertimbanga } \\
\text { n utama } \\
\text { Pencahayaan } \\
\text { dan } \\
\text { penghawaan } \\
\text { alami } \\
\text { penting }\end{array}$ & $\begin{array}{l}\text { Ekspos } \\
\text { selubung } \\
\text { bangunan } \\
\text { harus terlihat } \\
\text { jelas } \\
\text { Berada pada } \\
\text { bentang } \\
\text { struktur } \\
\text { yang cukup } \\
\text { lebar } \\
\text { Area } \\
\text { semioutdoor }\end{array}$ \\
\hline $\begin{array}{l}\text { Semi } \\
\text { publik }\end{array}$ & $\begin{array}{l}\text { Sekolah } \\
\text { Bisnis }\end{array}$ & $\begin{array}{l}\text { Pencapaian } \\
\text { telihat } \\
\text { Noise } \\
\text { penting } \\
\text { Pencahayaan } \\
\text { dan } \\
\text { penghawaan } \\
\text { alami + } \\
\text { buatan }\end{array}$ & $\begin{array}{l}\text { Area indoor } \\
\text { Ekspose } \\
\text { selubung } \\
\text { bangunan } \\
\text { Sekolah } \\
\text { Berada pada } \\
\text { bentang } \\
\text { struktur } \\
\text { yang kecil. }\end{array}$ \\
\hline Privat & $\begin{array}{l}\text { - Kantor } \\
\text { Sewa } \\
\text { - Pengelola } \\
\text { SOLO } \\
\text { GLOBE }\end{array}$ & $\begin{array}{l}\text { Pencapaian } \\
\text { telihat } \\
\text { Noise } \\
\text { penting } \\
\text { Pencahayaan } \\
\text { dan } \\
\text { penghawaan } \\
\text { alami + } \\
\text { buatan }\end{array}$ & $\begin{array}{l}\text { Area indoor } \\
\text { Ekspos } \\
\text { selubung } \\
\text { bangunan } \\
\text { Kantor } \\
\text { Berada pada } \\
\text { bentang } \\
\text { struktur } \\
\text { yang kecil }\end{array}$ \\
\hline Servis & $\begin{array}{l}\text { - Aea Servis } \\
\text { - Area Parkir }\end{array}$ & $\begin{array}{l}\text { Pencapaian } \\
\text { telihat }\end{array}$ & $\begin{array}{l}\text { Area } \\
\text { outdoor }\end{array}$ \\
\hline
\end{tabular}

Pada Tabel 2 terlihat persyaratan ruang yang dibutuhkan dalam menentukan pemintakatan wadah SOLO GLOBE.

\subsection{Analisis Faktor Bangunan}

\subsubsection{Analisis Bentuk Dasar Bangunan}

Dipertimbangkan dari penerapan konsep bentuk bangunan hybrid yaitu graft hybrid (Per, Mozas, Arpa, 2011) di mana bentuk dasar bangunan terlihat dengan penampilan ekspresi yang berbeda dari fungsifungsi di dalamnya (clear expression of program). Caranya adalah dengan mempertimbangkan bermacam-macam gubahan bentuk, seperti segitiga, segiempat, dan lingkaran yang kemudian mengalami proses penciptaan bangunan hybrid. Hal ini berdasarkan pertimbangan :

1. Karakter yang ditampilkan oleh bentukbentuk yang akan digunakan.

2. Jenis kegiatan yang diwadahi.

3. Kondisi tapak.

4. Fleksibilitas dalam penataan ruang.
5. Sesuai dengan penerapan bentuk graft hybrid.

6. Efisiensi fungsi dalam bentuk.

7. Nilai estetika bangunan.

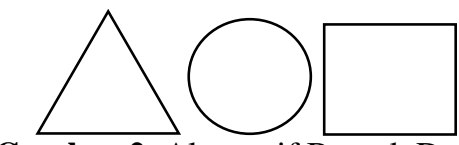

Gambar 2. Alternatif Bentuk Dasar

Pada Gambar 2 terlihat macam alternatif bentuk dasar bangunan yang dipilih untuk mewadahi macam kegiatan dan fungsi yang berbeda yaitu Sekolah Bisnis, Kantor Sewa dan Town Square sehingga karakter serta privasi masing-masing fungsi bangunan tetap terlihat walaupun digabungkan menjadi satu gubahan massa bangunan.

\subsubsection{Gubahan Massa Bangunan}

Terdapat beberapa hal terkait dengan dasar pertimbangan untuk menentukan pengolahan gubahan masa, yaitu sebagai berikut :

1. Gubahan masa yang dihasilkan dapat menggambarkan bangunan SOLO GLOBE sebagai wadah pendidikan dan bangunan komersial kegiatan bisnis di Kota Solo Baru.

2. Menghasilkan suatu performansi bangunan/fasade bangunan dari gubahan massa yang tercipta berdasarkan bentukbentuk dasar.

3. Perbedaan karakter kelompok kegiatan yang diwadahi.

4. Kesatuan antar fungsi kegiatan yang diwujudkan dalam konsep hybrid building.

5. Kesinambungan sirkulasi dalam bangunan.

6. Efektivitas dan optimalisasi penggunaan lahan.

Sebagai contoh pandangan secara umum dari bentuk bangunan menggunakan konsep hybrid bila diterapkan pada fisik bangunan Sekolah Bisnis, berupa deretan ruang kelas yang terlihat melalui deretan jendela pada fasade bangunan. Sama halnya dengan Sekolah Bisnis, untuk bangunan Kantor Sewa akan terlihat ruang-ruang yang terpola berdasarkan deretan jendela ruang kantor yang disediakan pada bangunan. 


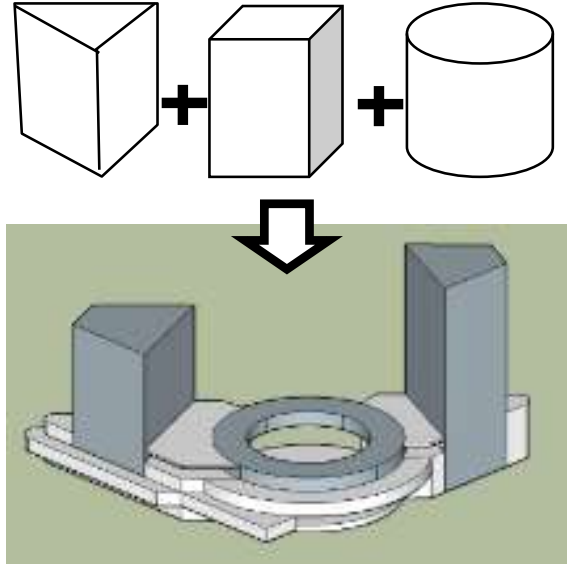

Gambar 3. Gubahan Massa SOLO GLOBE

Pada Gambar 3 terlihat deretan pola yang teratur tersebut dilambangkan dengan bentuk massa prisma dan balok untuk Sekolah Bisnis dan kantor Sewa, sedangkan untuk bangunan Town Square, akan terlihat deretan show-cases (ruang pamer produk) yang dilambangkan dengan bentuk massa tabung atau silinder.

Bangunan SOLO GLOBE yang terdiri dari tiga macam fungsi ini harus tetap memiliki karakter dari ketiga fungsi tersebut (disperate program). Oleh karena itu bangunan dimungkinkan memiliki kemajemukan bentuk yang masing-masing menggambarkan kegiatan ruang yang ada di dalamnya.

\subsubsection{Analisis Tampilan Bangunan}

Tujuannya untuk mendapatkan fasade yang sesuai dengan konsep bangunan hybrid.

Dasar pertimbangan berdasarkan prinsipprinsip bangunan vertikal, daya tarik pada bangunan didominasi oleh fungsi Town Square, pemilihan struktur yang dapat mewadahi bentuk tampilan yang direncanakan. Proses analisis :

1. Karena mewadahi macam kegiatan pendidikan, perkantoran dan hiburan, maka pemilihan warna dan penggunaan material harus dapat menggambarkan karakter masing-masing fungsi yang berbeda tersebut.

2. Pemilihan struktur yang sesuai dengan bentuk gubahan bangunan dapat menambah estetika tampilan bangunan SOLO GLOBE.

Citra pada tampilan bangunan terlihat dengan menampilkan perbedaan pola secondary skin pada facade, penggunaan material dan perbedaan besaran volume bangunan terhadap masing-masing fungsi dalam bangunan.

\section{KESIMPULAN (KONSEP DESAIN)}

Konsep Perancangan Solo Global Business Erudition (SOLO GLOBE) mengacu pada penggabungan macam fungsi bangunan sebagai Sekolah Bisnis, Kantor Sewa dan Town Square ke dalam satu wadah bangunan dimana Town Square merupakan hasil penggabungan secara hybrid.

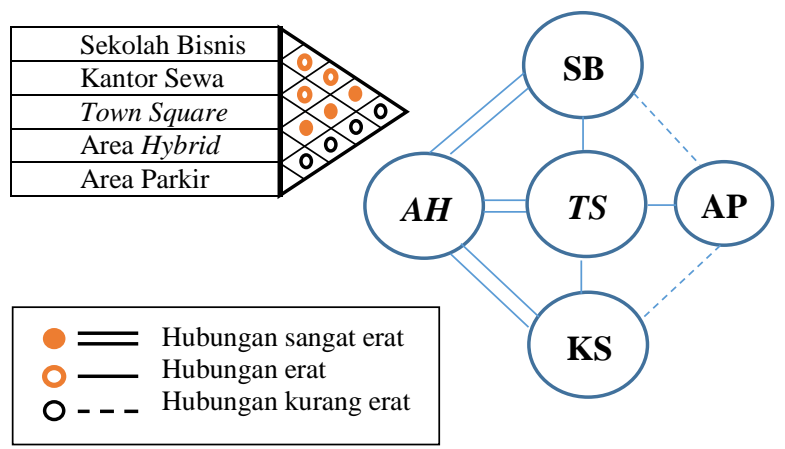

Gambar 4. Matriks Pola Hubungan Ruang

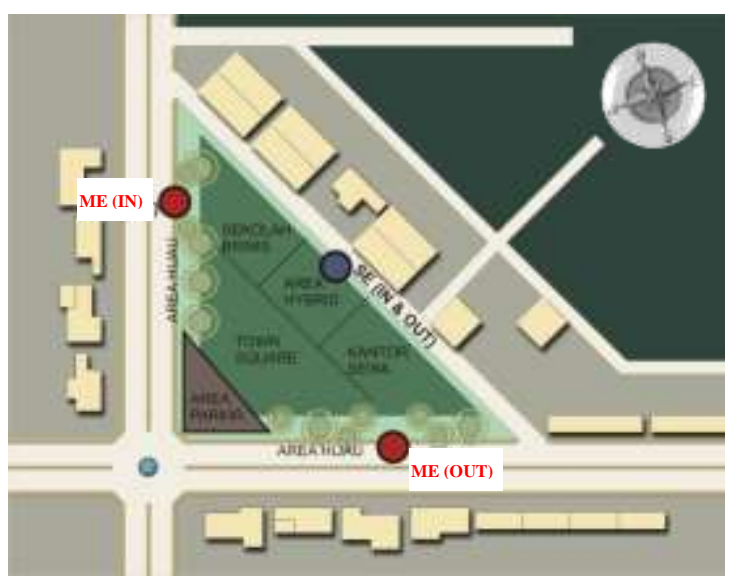

Gambar 5. Zonifikasi Horizontal Bangunan

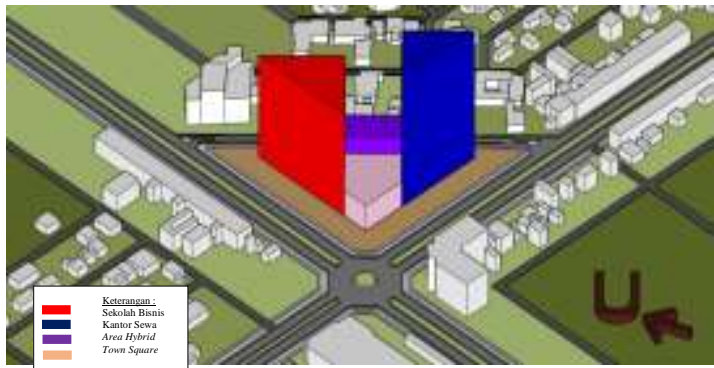

Gambar 6. Zonifikasi Vertikal Bangunan

Penggabungan tersebut berdasarkan penerapan disperate program (pemisahan zona) pada pola hubungan ruang dan pemintakatan bangunan yang dapat terlihat pada Gambar 4, 5 dan 6. 


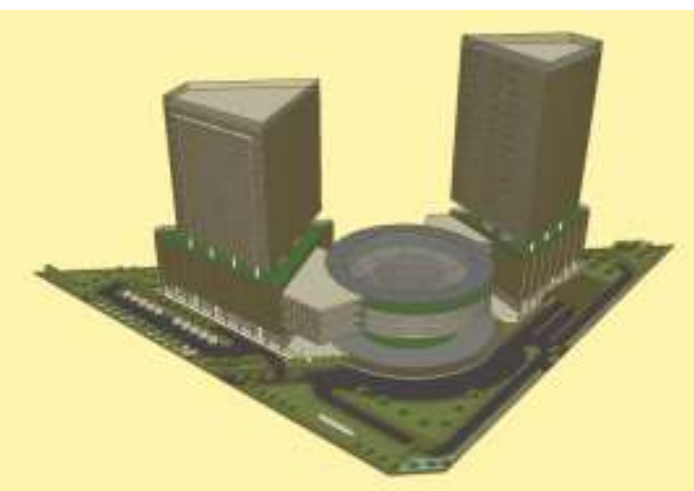

Gambar 7. Konsep Tampilan Dan Gubahan Massa SOLO GLOBE

Pada Gambar 7 dapat terlihat bahwa penerapan graft hybrid pada bentuk Sekolah Bisnis dan Kantor Sewa berasal dari bentuk prisma yang digabungkan dengan bentuk balok dan melambangkan karakter tower pada Bangunan SOLO GLOBE.

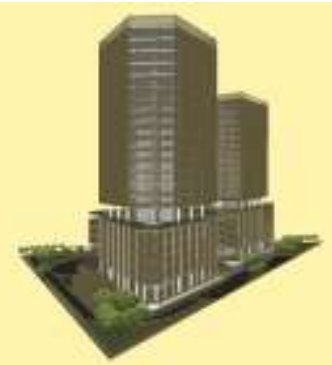

Gambar 8. Eksterior Selatan SOLO GLOBE

Pada Gambar 8 dapat terlihat pola secondary skin dan perbedaan volume besaran tower antara Sekolah Bisnis dengan Kantor Sewa agar karakter dari masing-masing fungsi tetap muncul serta unity antar masing-masing fungsi tersebut.

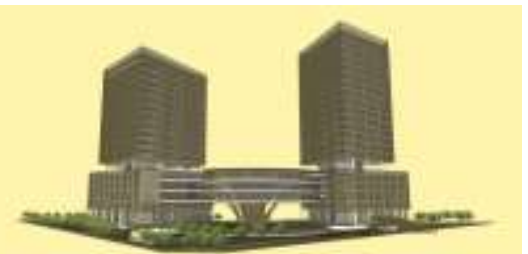

Gambar 9. Eksterior Timur Laut SOLO GLOBE

Penerapan graft hybrid pada bentuk Town Square berasal dari bentuk silinder dengan kesan melayang yang diapit oleh kedua tower Sekolah Bisnis dan Kantor Sewa. Pemilihan bentuk silinder yang melambangkan karakter dari sebuah podium pada SOLO GLOBE dapat terlihat pada Gambar 9.

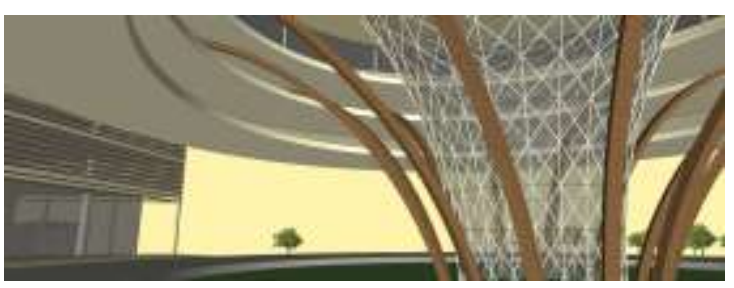

Gambar 10. Interior Cirle Point (Town Square)

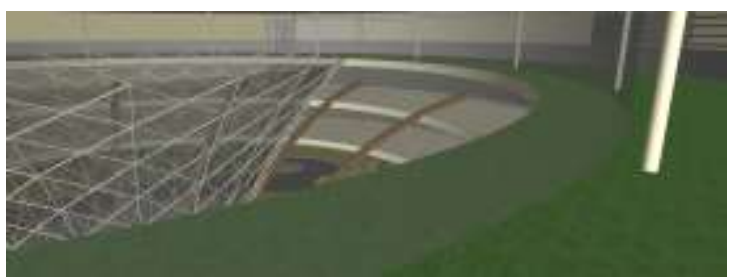

Gambar 11. Interior Sky Garden (Town Square)

Pada Gambar 10 dan 11 dapat dilihat hasil dari penggabungan fungsi bangunan pada SOLO GLOBE dengan Konsep Hybrid Building pada Area Circle Point yang merupakan bagian dari fungsi Town Square pada umumnya dan Area Hybrid pada khususnya. Dasar penggabungan, program penggabungan, ruang antara, bentuk, gubahan masa dan tampilan/fasade bangunan menjadi aspek terpenting dalam mendesain suatu bangunan berdasarkan konsep bangunan hybrid.

Dari hasil analisa serta hasil korelasi dari beberapa data di atas, maka diperoleh hasil berupa rancangan Solo Global Business Erudition di Solo Baru sebagai berikut.

Nama Bangunan : SOLO GLOBE

$\begin{array}{llr}\text { Lokasi } & \text { Jl. Ir. } & \text { Soekarno, } \\ & \text { Kecamatan } & \text { Grogol, } \\ \text { Kabupaten } & \text { Sukoharjo, } \\ & \text { Solo Baru } & \\ \text { Luas Lahan } & : 16.200 \mathrm{~m}^{2} & \\ \text { Luas Bangunan } & : 60.000 \mathrm{~m}^{2} \\ \text { Daya Tampung } & : 4.000 \text { orang } \\ \text { Kegiatan } & : \text { Pendidikan, Perkantoran, } \\ & \text { Perdagangan dan Hiburan }\end{array}$




\section{REFERENSI}

Badan Pusat Statistik Kabupaten Sukoharjo tahun 2014 tentang Jumlah Kepala Keluarga dan Rata-rata Jumlah Anggota Keluarga menurut Kecamatan 2014

Fenton, Joseph. (1985). Phamflet Architecture No.11: Hybrid Building. New York

Per, Aurora Fernández; Mozas, Javier ; Arpa, Javier. (2011). This Is Hybrid. Penerbit Graficas Santamaria. Victoria-Gasteiz

http://sukoharjokab.bps.go.id/linkTabelStatis/v iew/id/18 (diunduh 8 Juni 2014) 